\title{
A farewell to Dr Thomas Knacker (* 29.04.1951 - † 30.10.2011): scientific contributions and personal memories
}

\author{
Jörg Römbke ${ }^{1 *}$, Anja Coors ${ }^{1}$, Kathrin Fenner ${ }^{2}$, John Jensen ${ }^{3}$, Hans Løkke ${ }^{3}$, Christoph Schäfers ${ }^{4}$, \\ Jürg Oliver Straub ${ }^{5}$ and Chris Metcalfe ${ }^{6}$
}

\begin{abstract}
On October 30, 2011 we lost Dr. Thomas Knacker, a much valued and loved colleague, research partner and friend. We deeply regret the loss of an internationally honoured ecotoxicologist. The colleagues and friends that wish to express their sorrow in this contribution include individuals from a variety of organisations and academic institutions in Europe and abroad.
\end{abstract}

Keywords: Ecotoxicology, Environmental risk assessment, Memorial

\section{Thomas Knacker: his Life and Career Dr Jörg Römbke, Dr Anja Coors}

Thomas Knacker was born in Wüstensachsen, a small village in East Hesse in what was then the Federal Republic of Germany, close to the border to the former East Germany (Figure 1). Despite living most of his life in Frankfurt and travelling all over the world, he always kept very close connections to his home region. As a young man, he served as a German Federal Border Guard (1969-1971), a period he later called the most boring time of his life. While he was never a typical member of the 1968 student movement, he kept, often with fine humour, his distance from authorities and he had a strong sense of social justice. Between 1972 and 1977, he studied biology, in particular plant physiology, biochemistry and microbiology at the Johann Wolfgang Goethe-University in Frankfurt am Main, serving several years as an elected student representative in the university council. Afterwards, while being supported by the "German National Merit Foundation", he completed his Ph.D. thesis entitled "Measurements of the lipid content and the $\mathrm{CO}_{2}$-gas cycle and determinations of growth characteristics of Amaranthus paniculatus being grown under different oxygen concentrations" (1981) [1-3]. After a short stay at a governmental

\footnotetext{
* Correspondence: j-roembke@ect.de

${ }^{1}$ ECT Oekotoxikologie GmbH, Boettgerstr. 2-14, Flörsheim 65439, Germany

Full list of author information is available at the end of the article
}

agency, he continued his studies on plant physiology at the Department of Biochemistry at the University College in Cardiff (Wales, UK). The time spent in Cardiff instilled in him a deep interest in and fondness for the English language and culture and rewarded him with longlasting friendships.

After his return to Germany, Thomas Knacker changed his scientific orientation considerably by joining the Battelle Institute in Frankfurt (1983). This private American contract research institute (in fact at that time the biggest world-wide) was focused on applied research. He was hired to set up a working group in ecotoxicology; a field of science barely established back then. Starting with three colleagues and using his broad and profound biological knowledge, Thomas Knacker built up a department with more than 30 employees, covering all aspects of testing for aquatic and terrestrial effects and environmental fate. During this time, his interests expanded far beyond his scientific background (Figure 2). Already in those years his characteristic personal strengths became evident; in particular, his ability to approach people with very different backgrounds, regardless of whether they are employees, clients or colleagues. Despite having never been trained professionally in personnel management (or, by the way, in bookkeeping and business administration), the Department of Ecotoxicology quickly became well known for its 


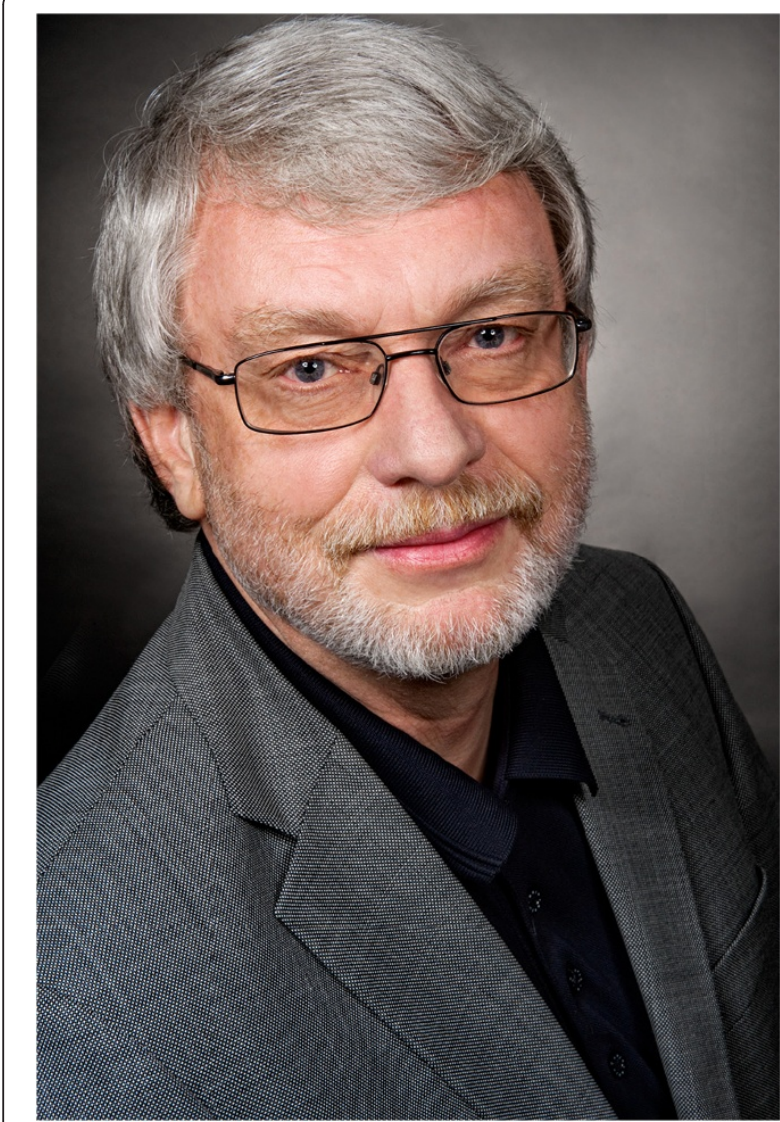

Figure 1 Thomas Knacker in 2011.

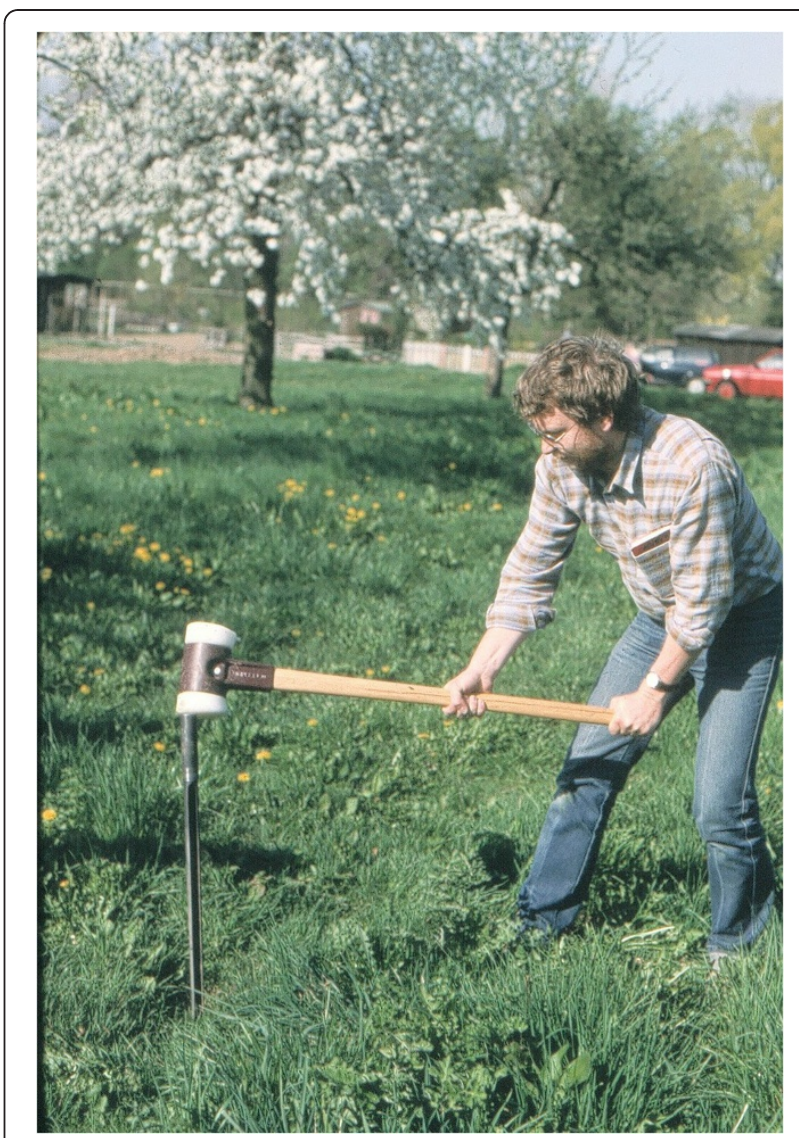

Figure 2 Thomas Knacker during field work near Frankfurt (1990).

scientific reputation, financial success, and great working atmosphere.

His strengths were especially required when Battelle decided to close its site in Frankfurt in 1993. Without those skills and a clear vision to stay independent, it would not have been possible to found in 1994 the independent company, ECT Oekotoxikologie GmbH. His founding partners were Hans Schallnass, who died much too early in 2007, and Jörg Römbke (Figure 3).

The same personal strengths that Thomas demonstrated during his time with Battelle guaranteed the success of ECT $\mathrm{GmbH}$, together with a unique business model that was a tightrope walk between applied research and testing services. This basic concept of a delicate balance between research and consultancy did not change during the steady growth of the company staff from six in the first laboratory at Bad Soden to about 30 at Flörsheim today. Among his many duties as a managing director were, to name just a few, strategic planning, project acquisition, human resource management and, most "preferred", controlling finances. However, from the inception of the company, Thomas' priority was always the scientific work, in the broadest sense. This includes the writing and reviewing of publications

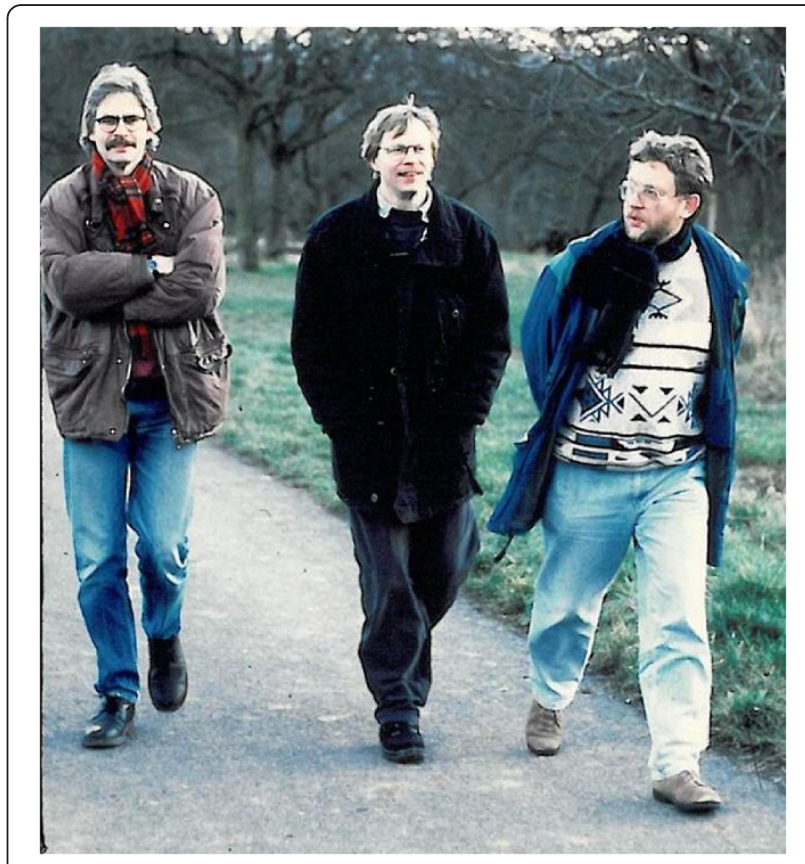

Figure 3 Jörg Römbke, Hans Schallnass and Thomas Knacker around 1993. 


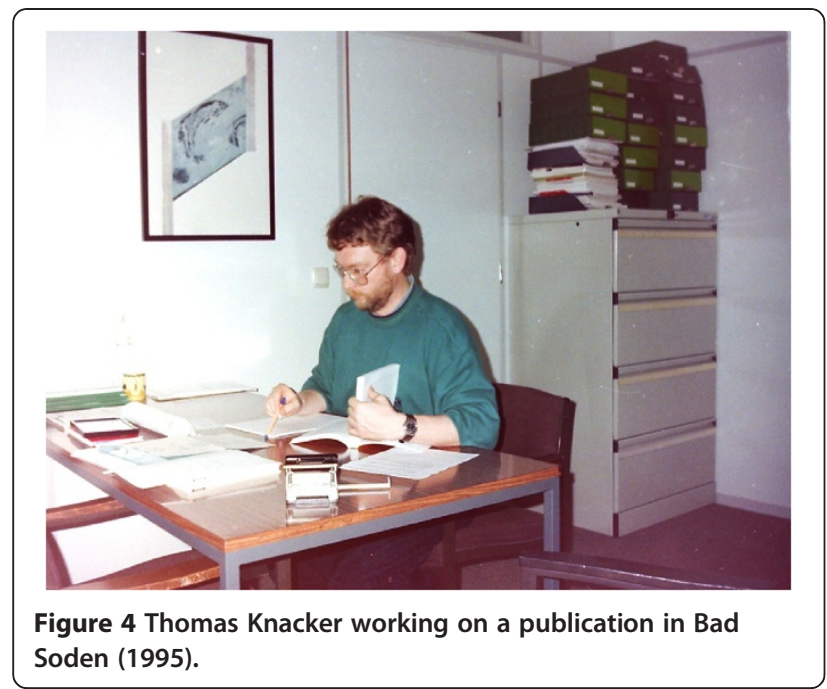

(Figure 4), the design and coordination of research projects and increasingly, consulting work with clients, including both industry and government agencies. He was the coordinator of two large EU projects, Terrestrial Model Ecosystems and ERAPharm (2004-2007). Although Thomas was formally responsible for aquatic ecotoxicology at ECT GmbH, his research interests were much broader [4-7]. His influence was probably most visible in the environmental risk assessment of chemicals [8-10], such as their regulation in the marine environment (OSPAR process), the effects of endocrine disruptors $[11,12]$ or their testing in higher-tier studies, especially Terrestrial Model Ecosystems (TMEs) [13-15]. In particular, he strongly contributed to the development of concepts for the evaluation and management of pharmaceuticals [16-18]. Recently, Thomas focused his activities on the outcome of the ERAPharm project [19-23].

Thomas Knacker dedicated most of his professional life to the science of ecotoxicology. For about 25 years he participated in scientific discussions, by giving lectures and talks but also by moderating workshops or public discourses (Figure 5). Thomas Knacker was a founding member of the German Language Branch (GLB) of the Society of Environmental Toxicity and Chemistry (SETAC), where he served the society as treasurer for many years. More recently, he was a member of the executive board of the environmental chemistry and toxicology subgroup within the GDCh (Gesellschaft Deutscher Chemiker). His public work was characterised by his expertise as a scientist, in combination with his broad scientific knowledge that extended beyond ecotoxicology, or even biology. But most important for his many friends and colleagues was his ability to listen to people and give them his time. Thomas Knacker possessed immense patience, which perfectly suited him for roles as a conciliator,

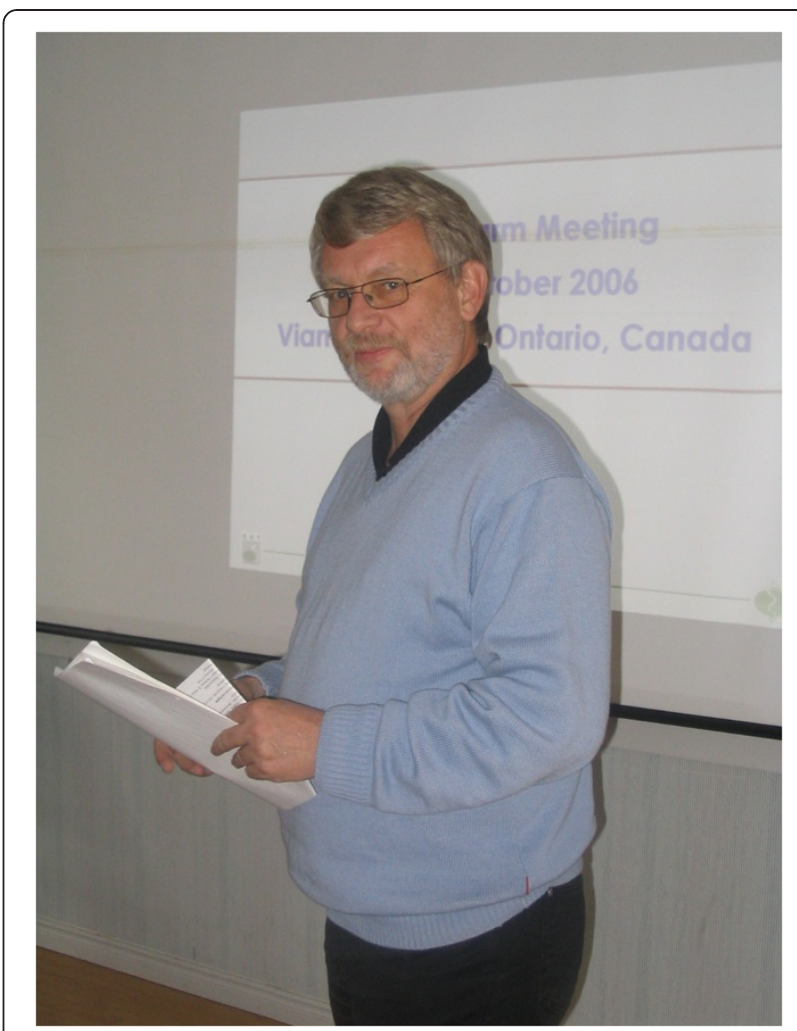

Figure 5 Thomas Knacker moderating a workshop of the ERAPharm project (2006).

both within the company and with third parties. While never giving up his own opinions or beliefs, he was one of those rare people that can truly accept the point of view of others. Together with his ability to develop strategic visions, this personal strength was the basis for his highly esteemed talent as a moderator and a mediator.

Until the very end, Thomas Knacker enjoyed his life. He was always a very sociable person and was involved in sports. For instance, he was an expert at football

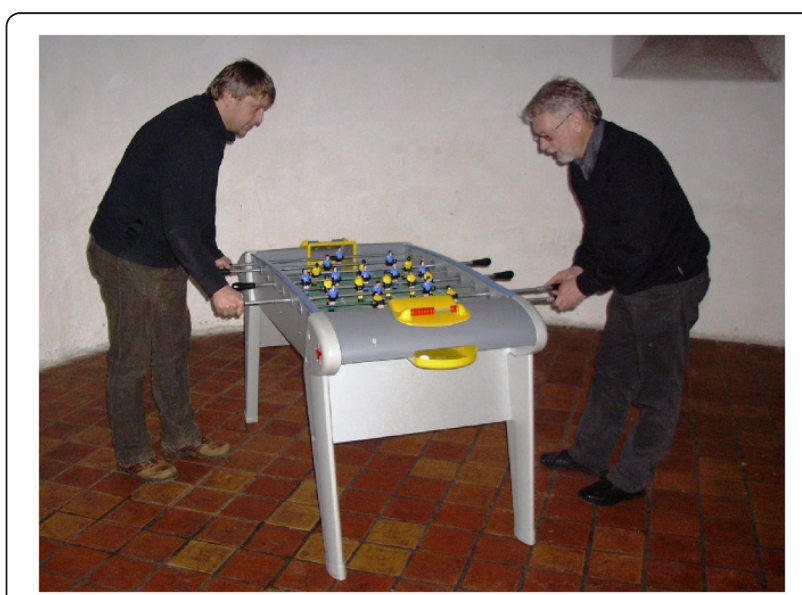

Figure 6 Table football at the ECT Christmas party (2010). 
(Figure 6). Our condolences and thoughts go out to his wife Margitta, to his daughter Katharina and to his family.

\section{Memories of Thomas Knacker as Scientist, Project Leader and Mentor PD Dr Kathrin Fenner}

I first got to know Thomas when he initiated discussions with several colleagues about submitting a proposal to the EU 6th framework program for what turned out to become the "ERAPharm" project. As a young postdoctoral researcher, this was the first time I was involved in such a large project, and from the very beginning I was impressed with the calm, but at the same time very decided manner with which Thomas moderated discussions amongst a bunch of preoccupied, too-busy-to-think scientists. Throughout the ERAPharm project, he would ask critical questions on all aspects of science, ranging from analytical chemistry to exposure modeling, and all the way to ecotoxicity testing and new conceptual approaches for risk assessment. While upon closer inspection his questions usually directly targeted the core problem, they were always posed in a very gentle way. I believe that all of us can remember Thomas sitting in his chair, in thinker pose, and asking: "Did I understand this right? You pointed out that. ..".

As the project went on, it also became clear that he was strategically extremely smart. He knew exactly about the "inner workings" of the three important parties involved in such a project, that is, the scientists, the EU commissioners, and the advisory board composed of stakeholders from very different institutions. He managed to keep all of their interests balanced and focused on achieving a positive outcome for the project. This might have been helped by his profound conviction that regulatory risk assessment should ultimately be driven by sound science. Finally, I will never forget when he asked me to lead one of the work packages in the project, and simply refused to take notice of my concerns about being too young, not in a secure position etc. I am sure that this experience as a work package leader has helped me in many ways to pursue my scientific career, and it most likely would not have happened in the same way without Thomas' encouragement.

\section{Thomas Knacker: international Cooperation among Friends}

Dr Hans Løkke (Emeritus) and Dr John Jensen

We were both deeply saddened by the news that Thomas Knacker had passed away. Over the past few decades, we got to know Thomas through the relatively small ecotoxicology network in Europe. He was one of the firstmovers in a novel scientific research area and a visionary, as well as a leader and manager. We and co-workers at the Danish National Environmental Research Institute frequently benefitted from the dynamic and creative level of cooperation we had with Thomas and his staff at ECT Oekotoxikologie $\mathrm{GmbH}$. Thomas had the special ability to perform as the manager of ECT providing ecotoxicological services for industry and governmental authorities, and at the same time excel as a dedicated researcher with a focus on microcosm and mesocosm studies in the aquatic and terrestrial environment, including the fate and effects of chemicals.

As the coordinator of NoMiracle, Hans Løkke appreciated Thomas very much as an experienced and wideranging researcher who generously gave scientific and social contributions to the NoMiracle Project. ECT contributed with studies on degradation kinetics and metabolite formation in sediment and water. In the NoMiracle project, Thomas supervised the PhD work of Thomas Junker, who developed and tested a watersediment screening tool based on the OECD Guideline $301 \mathrm{C}$ (MITI) to generate biodegradation data, which was the first water-sediment test system on screening test level. The work included the rates of elimination, turnover and mineralisation and the formation of non-extractable residues, as well as detailed checks for confounding factors such as high volatility, low solubility and high bacterial toxicity of the compounds under investigation. When we planned the 4th Open NoMiracle Workshop, entitled "Integrated Assessment of Environmental and Human Health" I phoned Thomas to find a suitable venue in Frankfurt which is located near the centre of Europe and with good connections for all travelers from our continent. He recommended the Mercure Hotel in Frankfurt, which then housed the workshop over 8-9 September 2008.

Through occasional conversations about leadership and the problems which Thomas and Hans jointly faced during their involvement in EU projects, Thomas willingly shared his experiences. Being a member of the Editorial Board for a period, Hans also remembers Thomas as a patient and ambitious Editor-in-Chief of the newly established Journal of Soils and Sediments (Figure 7).

Besides the treasured remembrances of wide-ranging professional interactions within ecotoxicology, John Jensen specifically remembers Thomas as a solid, determined, ambitious and yet friendly and sociable coordinator of the successfully ERAPharm project in the period 2004-2007. Thanks to his enthusiasm and his ability to encourage and initiate transnational and transatlantic cooperation, the ERAPharm project significantly contributed to advancing environmental risk assessment of pharmaceuticals within the EU and internationally. Thomas had a special talent for staff-management and supervision, which he successfully used in the ERAPharm project by setting up a solid and firm direction and framework within which he 


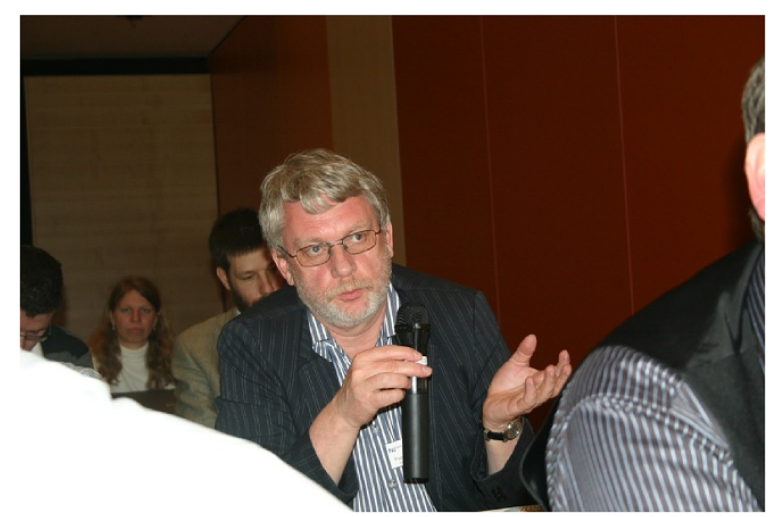

Figure 7 Thomas Knacker participating in the discussions at the 3rd NoMiracle International Workshop on Novel Methods for Assessing Chemical Exposure for the 21st Century, held in Leipzig 1-2 April 2008.

enabled the partners to use their individual skills and talents freely. These strengths, combined with a natural talent for teambuilding and fostering social interactions, made him a well-respected coordinator. Most predominant in my memory was a very successful project meeting in Canada hosted by our Canadians partners but competently organised by Thomas and his staff from abroad.

We will both miss Thomas as a friend and good colleague. All honour to his memory! (Figure 8).

\section{Thomas Knacker: Competitor, reliable Project Partner and Friend Dr Christoph Schäfers}

The aquatic ecotoxicology working group of Roland Nagel at the University of Mainz was situated close to Thomas Knacker's ECT, geographically as well as scientifically. Consequently, a substantial number of my

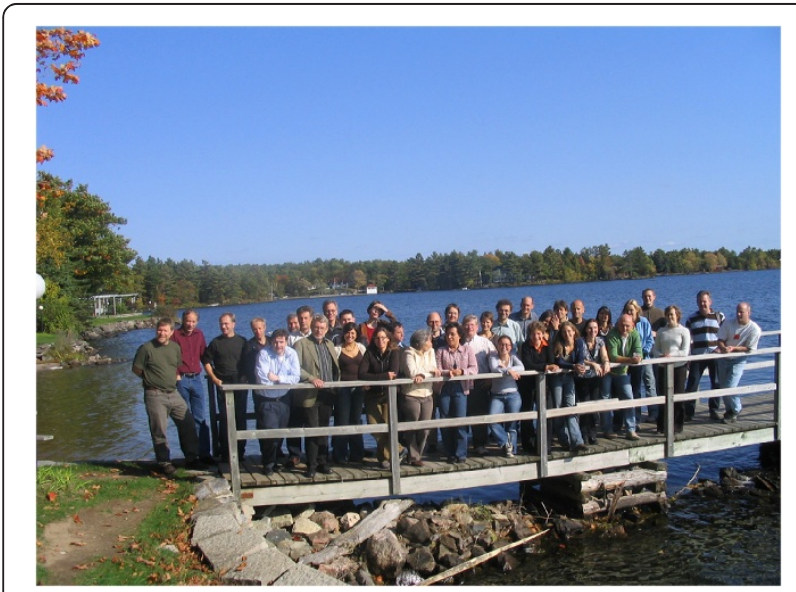

Figure 8 Thomas Knacker in the front row of the ERAPharm group at Stony Lake, Ontario, Canada, October 2006. colleagues within this group worked at ECT as postdoctoral scientists, either using it as a stepping stone into positions in industry or their own companies, or taking part in the development of ECT by staying as permanent staff.

When I started project acquisition and management for Fraunhofer IUCT (now IME) in the field of research and development of fish full life cycle tests, as well as of GLP studies using flow-through systems, I got to know Thomas Knacker as a strong competitor, since ECT and Fraunhofer IUCT shared objectives (applied research and contract work), approaches (regulatory concept development) and clients (regulatory authorities and industry). But at the same time, Thomas turned out to be a person much more interested in the scientific development of an issue than in claiming exclusive rights to it. Even for contract work, Thomas was willing to share his extensive experience. For instance, ECT constructed our flow-through facility for radiolabelled substances. In the last twelve years, we closely cooperated in many public research and development projects as well as in GLP studies for industry. Thomas was known for his timely and thorough contributions and was our favourite partner when regulatory needs of chemical safety legislation had to be considered. He was calm and competent as communicative project manager, as well as a moderator of workshops with regulators and industry. As a striking trait of his character, he showed fair-minded openness and diplomacy: Thomas could combine them effortlessly. Besides project cooperation, Thomas was helpful in giving advice for handling problems related to personnel and finance management, talking about strategic vision and sharing political and social opinions. We never acknowledged a close personal relationship, but now I am aware that I have lost a friend.

\section{Thomas Knacker: Impressions of a Gentleman Scientist}

\section{Dr Jürg Oliver Straub}

I first met Thomas Knacker as the project leader of ERAPharm when I was invited to join the Advisory Board as an industry representative. My first impression has lasted all those years: an unobtrusive man with a gentle manner, a fine sense of humour, an open mind, an intellectual horizon well beyond the limits of science, a quick intellect, high technical competence in environmental research and obvious experience in scientific projects. Together with his sensitive social skills, this set of personality traits allowed him to lead a very diverse group of scientists both softly and gracefully, yet firmly.

After ERAPharm we kept friendly contact through scientific congresses and meetings, as well as through contract work by ECT for the regulatory needs of my company. Particularly in the latter role, he shared his 
wide experience in environmental fate and effects testing, from strategies to follow to details of single assays, providing both sound and frank advice. It was always a pleasure to be in his company, be it for a day's work or for a social evening. Altogether, over the years I have learnt a lot from this particular gentleman scientist.

The news of his untimely demise came unexpectedly and bitterly. As we all do, I miss his staunch, goodhumoured, friendly presence. I would like to extend my sincere condolences to his family, his close friends, his collaborators at ECT and his many colleagues in the field of environmental sciences worldwide.

\section{Reflections on Thomas Knacker \\ Dr Chris Metcalfe}

Thomas Knacker worked too hard; an affliction that affects many of us in the field of science. His wife, Margitta affectionately complained that he even brought his laptop on vacations. Yet, I never got the impression that his hard work was motivated by personal ambition, but was rather motivated by a sense of responsibility to his company, his employees and his colleagues that drove him to put in those long hours. To a certain extent, his work defined him as a person and provided him with the network of friends and colleagues that sustained him. My impressions of Thomas are of a man with a nimble mind, who was a fine judge of people and character. $\mathrm{He}$ gave of himself unreservedly and with good humour. For these human qualities he will be remembered as a fine colleague and friend. For his scientific track record, he will be remembered as a damned good researcher.

\section{Competing interests}

The authors declare that they have no competing interests.

\section{Authors' contributions}

$\mathrm{JR}$ and $\mathrm{AC}$ developed the concept of this obituary and wrote the Chapter

"Thomas Knacker: his Life and Career". KF, JJ, HL, CS, JOS and CM contributed equally to the remaining content of this obituary. All authors read and approved the final manuscript.

\section{Author details}

${ }^{1}$ ECT Oekotoxikologie GmbH, Boettgerstr. 2-14, Flörsheim 65439, Germany. ${ }^{2}$ Department of Environmental Chemistry, Eawag, P.O. Box 611, Dübendorf $\mathrm{CH}-8600$, Switzerland. ${ }^{3}$ Department of Bioscience, Aarhus University, Vejlsøvej 25, Silkeborg DK-8600, Denmark. "Fraunhofer IME, Auf dem Aberg 1, Schmallenberg 57392, Germany. ${ }^{5}$ F. Hoffmann-La Roche Ltd, Group SHE, Basle CH-4070, Switzerland. ${ }^{6}$ Trent University, 1600 West Bank Drive, Peterborough, ON K9J 7B8, Canada.

Received: 5 July 2012 Accepted: 15 July 2012

Published: 30 October 2012

\section{References}

1. Knacker $T$, Schaub $H$ : The effect of low oxygen concentration on the acyl-lipid and fatty-acid composition of the $\mathrm{C}_{4}$ plant Amaranthus paniculatus. Planta 1984, 162:441-449.

2. Knacker T, Unter CN, Jones OTG, Russell NJ, Harwood JL: Acyl lipid changes in photosynthetic mutants of Rhodopseudomonas sphaeroides correlate with blocks in bacteriochlorophyll synthesis. FEMS Microbiology Letters 1985, 27:155-159.
3. Rudolf $W$, Knacker $T$, Schaub $H$ : The effect of low oxygen concentration on the cytokinin content of the $C_{4}$ plant Amaranthus paniculatus. Biochem Physiol Pflanzen 1987, 182:203-211.

4. Römbke J, Knacker T: Aquatic toxicity test for enchytraeids. Hydrobiologia 1989, 180:235-242.

5. Kalsch W, Knacker T, Robertz M, Studinger G, Franke C: Partitioning and mineralization of $\left[{ }^{14} \mathrm{C}\right]$ Lindane in a laboratory sediment-water system. Envir Toxicol Chemistry 1998, 17:662-669.

6. Egeler P, Römbke J, Meller M, Knacker T, Nagel R: Bioaccumulation Test with Tubificid Sludgeworms (Oligochaeta) in Artificial Media - Development of a Standardisable Method. Hydrobiologia 1999, 406:271-280.

7. Liebig M, Schmidt G, Bontje D, Kooi BW, Streck G, Traunspurger W, Knacker T: Direct and indirect effects of pollutants on algae and algivorous ciliates in an aquatic indoor microcosm. Aquatic Toxicology 2008, 88:102-110.

8. Klaschka U, Liebig M, Knacker T: Eco-labelling of shampoos, shower gels and foam baths. ESPR -Environ Sci Poll Res 2007, 14:24-29.

9. Reuschenbach P, Silvani P, Dammann M, Warnecke D, Knacker T: ECOSAR model performance with a large test set of industrial chemicals. Chemosphere 2008, 71:1986-1995.

10. Knacker T, Coors A: Ökotoxikologische Bewertung von anthropogenen Stoffen acatech Materialien - Nr. 10. München, Germany: Deutsche Akademie der; 2011.

11. Liebig M, Egeler P, Oehlmann J, Knacker T: Bioaccumulation of 14C-17aethinylestradiol by the aquatic oligochaete Lumbriculus variegatus in spiked artificial sediment. Chemosphere 2005, 59:271-280.

12. Knacker T, Boettcher M, Frische T, Rufli H, Stolzenberg HC, Teigeler M, Zok S, Braunbeck T, Schäfers C: Environmental effect assessment for sexual endocrine-disrupting chemicals: fish testing strategy. Integr Environ Assess Manag 2010, 6:653-662.

13. Morgan E, Knacker T: The role of laboratory terrestrial model ecosystems in the testing of potentially harmful substances. Ecotoxicology 1994, 3:213-233.

14. Knacker T, Förster B, Römbke J, Frampton G: Assessing the effects of plant protection products on organic matter breakdown in arable fields. Soil Biol Biochem 2003, 35:1269-1287.

15. Knacker T, Van Gestel CAM, Jones SE, Soares AMVM, Schallnaß HJ, Förster B, Edwards CA: Ring-testing and field validation of a terrestrial model ecosystem (TME) - an instrument for testing potentially harmful substances: conceptual approach and study design. Ecotoxicology 2004, 13:5-23

16. Römbke J, Knacker T, Teichmann H: Ecotoxicological evaluation of pharmaceuticals. In Pharmaceuticals and Personal Care Products in the Environment: Scientific and Regulatory Issues.Symposium Series 791, 2001 Edited by Daughton CG, Jones-Lepp TL. Washington DC: American Chemical Society; 2001:304-319.

17. Liebig M, Moltmann JF, Knacker T: Evaluation of measured and predicted environmental concentrations of selected human pharmaceuticals and personal care products. Environ Sci Poll Res 2006, 13:110-119.

18. Kools SAE, Boxall ABA, Moltmann JF, Bryning G, Koschorrek J, Knacker T: A ranking of European veterinary medicines based on environmental risks. Integr Environ Assess Manag 2008, 4:399-408.

19. Knacker T, Duis K, Ternes T, Fenner K, Escher B, Schmitt H, Römbke J, Garric J, Hutchinson T, Boxall ABA: The EU-project ERAPharm. Incentives for the further development of guidance documents? Environ Sci Poll Res 2005, 12:62-65.

20. Küster A, Alder AC, Escher B, Duis K, Fenner K, Garric J, Hutchinson TH, Lapen DR, Péry A, Römbke J, Snape J, Ternes T, Topp E, Wehrhan A, Knacker T: Environmental risk assessment of human pharmaceuticals in the European Union - a case study with the $\beta$-blocker atenolol. Integr Environ Assess Manag 2010, 6(Suppl 1):514-523.

21. Oakes KD, Coors A, Escher BI, Fenner K, Garric J, Gust M, Knacker T, Küster A, Kussatz C, Metcalfe CD, Monteiro S, Moon TW, Mennigen JA, Parrott J, Péry ARR, Ramil M, Roennefahrt I, Tarazona JV, Sánchez-Argüello P, Ternes TA, Trudeau VL, Boucard T, Van Der Kraak GJ, Servos MR: An environmental risk assessment for the serotonin re-uptake inhibitor fluoxetine - a case study utilizing the European risk assessment framework. Integr Environ Assess Manag 2010, 6(Suppl 1):524-539.

22. Liebig M, Alonso Fernandez Á, Blübaum-Gronau E, Boxall A, Brinke M, Carbonell G, Egeler P, Fenner K, Fernandez C, Fink G, Garric J, Halling-Sørensen B, Knacker T, Krogh KA, Küster A, Löffler D, Porcel Cots MÁ, 
Pope L, Prasse C, Römbke J, Rönnefahrt I, Schneider MK, Schweitzer N, Tarazona JV, Ternes TA, Traunspurger W, Wehrhan A, Duis K: Environmental risk assessment of ivermectin: a case study. Integr Environ Assess Manag 2010, 6(Suppl 1):567-587.

23. Tarazona JV, Escher BI, Giltrow E, Sumpter JP, Knacker T: Targeting the environmental risk assessment of pharmaceuticals: facts and fantasies. Integr Environ Assess Manag 2010, 6(Suppl 1):603-613.

doi:10.1186/2190-4715-24-33

Cite this article as: Römbke et al: A farewell to Dr Thomas Knacker

(* 29.04.1951 - † 30.10.2011): scientific contributions and personal memories. Environmental Sciences Europe 2012 24:33.

\section{Submit your manuscript to a SpringerOpen ${ }^{\circ}$} journal and benefit from:

- Convenient online submission

- Rigorous peer review

- Immediate publication on acceptance

- Open access: articles freely available online

- High visibility within the field

- Retaining the copyright to your article

Submit your next manuscript at $\gg$ springeropen.com 